\title{
Early Effects of P-15 on Human Bone Marrow Stem Cells
}

\author{
Vincenzo Sollazzo ${ }^{1}$, Annalisa Palmieri², Ambra Girardi ${ }^{2}$, Francesca Farinella ${ }^{3}$, and Francesco \\ Carinci $^{3}$
}

${ }^{1}$ Orthopedic Clinic, University of Ferrara, Ferrara, Italy

${ }^{2}$ Department of Histology, Embryology and Applied Biology, University of Bologna, Bologna, Italy

${ }^{3}$ Department of Maxillofacial Surgery, University of Ferrara, Ferrara, Italy

\author{
Corresponding Author: \\ Francesco Carinci, \\ Department of Maxillofacial Surgery \\ University of Ferrara \\ Corso Giovecca 203 \\ IT - 44100, Ferrara \\ Italy \\ Phone: 0039-0532-455582 \\ Fax: 0039-0532-455582 \\ E-mail: crc@unife.it
}

\begin{abstract}
Objectives: Peptide-15 (P-15) is an analogue of the cell binding domain of collagen. P-15 has been shown to facilitate physiological to process in a way similar to collagen, to serve as anchorage for cells, and to promote the binding, migration and differentiation of cells. However, how P-15 alters osteoblast activity to promote bone formation is poorly understood. To study the osteoinductive properties of peptide P-15, we analyzed the expression levels of bone related genes in human mesenchymal stem cells treated with this biomaterial.

Material and methods: Using real time Reverse Transcription-Polymerase Chain Reaction the quantitative expression of specific genes, like transcriptional factors (RUNX2 and SP7), bone related genes (SPP1, COL1A1, COL3A1, BGLAP, ALPL, and FOSL1) and mesenchymal stem cells marker (ENG) were examined.

Results: P-15 causes a considerable induction of osteoblast transcriptional factor like osterix (SP7) and of the bone related genes osteopontin (SPP1) and osteocalcin (BGLAP). In contrast the expression of endoglin (ENG) was markedly decreased in stem cells treated with P-15 respect to untreated cells, indicating the differentiation effect of this biomaterial on stem cells. Conclusion: The present study shows the effect of P-15 on mesenchymal stem cells in the early differentiation stages: P-15 is an inducer of osteogenesis on human stem cells as indicated by the activation of bone related markers SP7, SPP1 and BGLAP. The results may allow a better understanding of the molecular mechanism of bone regeneration and as a model for comparing other materials with similar clinical effects.
\end{abstract}

Keywords: stem cells; biomaterial; P-15; differentiation; bone.

Accepted for publication: 26 November 2009

To cite this article:

Sollazzo V, Palmieri A, Girardi A, Farinella F, and Carinci F. Early effects of P-15 on human bone marrow stem cells.

J Oral Maxillofac Res 2010 (Jan-Mar);1(1):e4

URL: http://www.ejomr.org/JOMR/archives/2010/1/e4/e4ht.pdf

doi:10.5037/jomr.2010.1104 


\section{INTRODUCTION}

Several studies have been involved in the identification of factors that could help in the regeneration of missing tissue [1]. One avenue of research has been the identification of the specific cell-binding domain of type I collagen [1]. Type I collagen represents approximately one third of the total body proteins. Collagen, moreover, is a major determinant of the architecture and tensile strength of the tissues, and it modulates cell proliferation, migration, differentiation, and specific gene expression [2]. P-15 is a highly conserved linear peptide with a 15-amino acid sequence identical to the sequence contained in the residues 766-780 of the alpha chain of type I collagen [1]. P-15 from DENTSPLY Friadent (CeraMed, Lakewood, CO, USA) is an analogue of the cell-binding domain of collagen [2]. P-15 competes for cell surface sites for attachment of collagen and, when immobilized on surfaces, it promotes adhesion of cells [3]. P-15 has been shown to facilitate physiological processes in a way similar to collagen, to facilitate the exchange of mechanical signals, and to promote cell differentiation [4-6]. Like other bone augmentation materials, P-15 associated with anorganic-derived bone matrix $(\mathrm{ABM})$, has been shown to be helpful in the treatment of periodontal defects, and sinus-lifting procedures $[1,7-11]$.

In previous studies a genome wide screening of osteoblast-like cell line (MG-63) following treatment with P-15 was performed by using cDNA microarray [12]. Several genes covering a broad range of functional activities, like signalling transduction, differentiation, apoptosis, cell-cycle regulation, were significantly up- or down-regulated [12]. Then the genetic effect of P-15 was studied in the same cell system at posttranscriptional level, with microRNA microarray $[13,14]$. A miRNA that regulates the transduction of genes related to bone formation (TFIP11), skeletal development (HOXD13, AEBP1, SHOX EN1 COMP SUFU IGF1 MATN1) and cartilage remodelling (NOG) was identified.

Because few reports analyze the effects of P-15 on stem cells [15] and none focus on the genetic effects, the expression of genes related to the osteoblast differentiation were analyzed using cultures of bone marrow derived human mesenchymal stem cells (BMhMSCs) treated with P-15 for seven days, in order to detect the early effects of the common path of BMPs on stem cells.

\section{MATERIAL AND METHODS}

The study was approved by the Ethics Committee of the Ferrara University.

\section{Stem cell preparation}

Bone marrow derived human mesenchymal stem cells (BM-hMSCs) were obtained from the three healthy adult volunteers. There were 2 males and 1 female (average age of volunteers was 45 years); experiments were done in duplicate.

Bone Marrow collected in heparinized tubes, was diluted 1 : 3 with phosphate buffered saline (PBS) (Lonza, Basel, Switzerland) and layered over a Ficoll-Histopaque gradient $(1.077 \mathrm{~g} / \mathrm{ml}$; Sigma, St. Louis, MO, USA). The low-density mononuclear cells were washed twice in PBS, counted and plated at $106 / \mathrm{cm}^{2}$ in cell culture flasks (BD Falcon, Bedford, MA, USA) in Dulbecco's Modified Eagle's Medium (DMEM) (Lonza, Basel, Switzerland) supplemented with $20 \%$ heat inactivated fetal bovine serum (FBS) (Lonza, Basel, Switzerland) and antibiotics (100 U/ml Penicillin, $100 \mu \mathrm{g} / \mathrm{ml}$ Streptomycin) (Sigma-Aldrich, Inc., St Louis, Mo, USA), and incubated at $37{ }^{\circ} \mathrm{C}$ in a humidified atmosphere with $5 \% \mathrm{CO}_{2}$. After 1 week, the non-adherent cells were removed by replacing the medium supplemented with $10 \%$ FBS. When the cultures were near confluence (after 2 weeks) the cells were recovered, by treatment with $1 \mathrm{X}$ trypsin/EDTA solution (Sigma-Aldrich, Inc., St Louis, Mo, USA), for cytometric analysis and functional assays. BM-hMSCs were maintained and subcultured for up to 10-15 passages.

\section{Immunofluorescence}

Cells were washed with PBS for three times and fixed with cold methanol for $5 \mathrm{~min}$ at room temperature. After washing with PBS, cells were blocked with bovine albumin 3\% (Sigma-Aldrich, Inc., St Louis, Mo, USA) for $30 \mathrm{~min}$ at room temperature. The cells were incubated overnight sequentially at $4{ }^{\circ} \mathrm{C}$ with primary antibodies raised against CD105 1:200, mouse (BD Biosciences, San Jose, CA, USA), CD73 1:200, mouse (Santa Cruz Biotechnology, Inc., Santa Cruz, CA, USA), CD90 1:200, mouse (Santa Cruz Biotechnology, Inc., Santa Cruz, CA, USA), CD34 1 : 200, mouse (Santa Cruz Biotechnology, Inc., Santa Cruz, CA, USA). They were washed with PBS and incubated for 1 $\mathrm{h}$ at room temperature with secondary antibody conjugated-Rodamine goat anti-mouse 1:200 (Santa Cruz Biotechnology, Inc., Santa Cruz, CA, USA). Subsequently, cells were mounted with the Vectashield Mounting Medium with DAPI (Vector Laboratories, Inc., Burlingame, CA, USA) and observed under a fluorescence microscope (Eclipse TE 2000-E, Nikon 
Instruments S.p.a., Florence, Italy).

\section{Cell culture}

BM-hMSCs at fourth passage were grown in medium (Alphamem-Sigma Aldrich, Inc., St Louis, Mo, USA) supplemented with $10 \%$ fetal calf serum, antibiotics (Penicillin $100 \mathrm{U} / \mathrm{ml}$ and Streptomycin $100 \mu \mathrm{g} /$ $\mathrm{ml}$ - Sigma-Aldrich, Inc., St Louis, Mo, USA) and amminoacids (L-Glutamine - Sigma-Aldrich, Inc., St Louis, Mo, USA). The cultures were maintained in a $5 \% \mathrm{CO}_{2}$ humidified atmosphere at $37^{\circ} \mathrm{C}$.

For the assay, cells were collected and seeded at a density of $1 \times 105$ cells $/ \mathrm{ml}$ into $9 \mathrm{~cm}^{2}(3 \mathrm{ml})$ wells by using $0.1 \%$ trypsin, $0.02 \%$ EDTA in $\mathrm{Ca}++-$ and $\mathrm{Mg}$ - free Eagle's buffer for cell release.

One set of wells were added with P-15 at the concentration of $10 \mu \mathrm{l} / \mathrm{ml}$. Another set of wells containing untreated cells were used as control. The medium was changed every 3 days.

After seven days, when cultures were subconfluent, cells were processed for RNA extraction.

\section{RNA processing}

Reverse transcription to cDNA was performed directly from cultured cell lysate using the TaqMAn Gene Expression Cells-to-Ct Kit (Ambion Inc., Austin, TX,
USA), following manufacturer's instructions. Briefly, cultured cells were lysed with lysis buffer and RNA released in this solution. Cell lysate were reverse transcribed to cDNA using the RT Enzyme Mix and appropriate RT buffer (Ambion Inc., Austin, TX, USA).

Finally the cDNA was amplified by real time PCR using the included TaqMan Gene Expression Master Mix and the specific assay designed for the investigated genes.

\section{Real time PCR}

Expression was quantified using real time RT-PCR. The gene expression levels were normalized to the expression of the housekeeping gene RPL13A and were expressed as fold changes relative to the expression of the untreated BM-hMSCs. Quantification was done with the delta/delta calculation method [16].

Forward and reverse primers and probes for the selected genes were designed using primer express software (Applied Biosystems, Foster City, CA, USA) and are listed in Table 1.

All PCR reactions were performed in a 20 $\mu 1$ volume using the ABI PRISM 7500 (Applied Biosystems, Foster City, CA, USA). Each reaction contained $10 \mu 1$ 2X TaqMan universal PCR master mix (Applied Biosystems, Foster City, CA, USA), $400 \mathrm{nM}$ concentration of each primer and $200 \mathrm{nM}$ of

Table 1. Primer and probes used in real time PCR.

\begin{tabular}{|c|c|c|c|}
\hline $\begin{array}{c}\text { Gene } \\
\text { symbol }\end{array}$ & Gene name & Primer sequence $\left(5^{\prime}>3^{\prime}\right)$ & Probe sequence $\left(5^{\prime}>3^{\prime}\right)$ \\
\hline SPP1 & osteopontin & $\begin{array}{l}\text { F-GCCAGTTGCAGCCTTCTCA } \\
\text { R-AAAAGCAAATCACTGCAATTCTCA }\end{array}$ & CCAAACGCCGACCAAGGAAAACTCAC \\
\hline COL1A1 & collagen type I alphal & $\begin{array}{l}\text { F-TAGGGTCTAGACATGTTCAGCTTTGT } \\
\text { R-GTGATTGGTGGGATGTCTTCGT }\end{array}$ & CCTCTTAGCGGCCACCGCCCT \\
\hline RUNX2 & $\begin{array}{l}\text { runt-related } \\
\text { transcription factor } 2\end{array}$ & $\begin{array}{l}\text { F-TCTACCACCCCGCTGTCTTC } \\
\text { R-TGGCAGTGTCATCATCTGAAATG }\end{array}$ & ACTGGGCTTCCTGCCATCACCGA \\
\hline ALPL & alkaline phosphatase & $\begin{array}{l}\text { F-CCGTGGCAACTCTATCTTTGG } \\
\text { R-CAGGCCCATTGCCATACAG }\end{array}$ & CCATGCTGAGTGACACAGACAAGAAGCC \\
\hline COL3A1 & $\begin{array}{l}\text { collagen, type III, } \\
\text { alpha } 1\end{array}$ & $\begin{array}{l}\text { F-CCCACTATTATTTTGGCACAACAG } \\
\text { R-AACGGATCCTGAGTCACAGACA }\end{array}$ & ATGTTCCCATCTTGGTCAGTCCTATGCG \\
\hline BGLAP & osteocalcin & $\begin{array}{l}\text { F-CCCTCCTGCTTGGACACAAA } \\
\text { R-CACACTCCTCGCCCTATTGG }\end{array}$ & CCTTTGCTGGACTCTGCACCGCTG \\
\hline CD105 & endoglin & $\begin{array}{l}\text { F-TCATCACCACAGCGGAAAAA } \\
\text { R-GGTAGAGGCCCAGCTGGAA }\end{array}$ & TGCACTGCCTCAACATGGACAGCCT \\
\hline FOSL1 & FOS-like antigen 1 & $\begin{array}{l}\text { F-CGCGAGCGGAACAAGCT } \\
\text { R-GCAGCCCAGATTTCTCATCTTC }\end{array}$ & ACTTCCTGCAGGCGGAGACTGACAAAC \\
\hline SP7 & osterix & $\begin{array}{l}\text { F-ACTCACACCCGGGAGAAGAA } \\
\text { R-GGTGGTCGCTTCGGGTAAA }\end{array}$ & TCACCTGCCTGCTCTTGCTCCAAGC \\
\hline RPL13A & ribosomal protein L13 & $\begin{array}{l}\text { F-AAAGCGGATGGTGGTTCCT } \\
\text { R-GCCCCAGATAGGCAAACTTTC }\end{array}$ & CTGCCCTCAAGGTCGTGCGTCTG \\
\hline
\end{tabular}


the probe, and cDNA. The amplification profile was initiated by 10 minute incubation at $95{ }^{\circ} \mathrm{C}$, followed by two-step amplification of 15 seconds at $95^{\circ} \mathrm{C}$ and 60 seconds at $60{ }^{\circ} \mathrm{C}$ for 40 cycles. All experiments were performed including nontemplate controls to exclude reagents contamination. PCRs were performed with two biological replicates.

\section{RESULTS}

BM-hMSCs were characterized by immunofluorescence. The cell surfaces were positive for mesenchymal stem cell marker, CD105, CD90 and CD73 and negative for markers of haematopoietic origin, CD34 (Figure 1).

Transcriptional expressions of several osteoblast-related genes (RUNX2， SP7， SPP1， COLIA1, COL3A1, BGLAP, ALPL and FOSL1) and mesenchymal stem cells marker (ENG) were examined after 7 days of supplement treatment with P-15 $(10 \mu \mathrm{l} / \mathrm{ml})$.

Quantitative real time RT-PCR of SP7, SPP1, BGLAP showed a considerable induction after treatment with P-15. However, P-15 treatment did not affect the mRNA expression of RUNX2 and ALPL that were similarly in both treated and untreated BM-hMSCs. COL1A1, COL3A1 and FOSL1 were decreased in the presence of P-15 at day 7 like the stem cell marker ENG (Figure 2).

\section{DISCUSSION}

In order to understand the action of P-15 on BM-hMSCs, changes in expression of bone related marker genes (RUNX2, SP7, SPP1, COLIA1, COL3A1, BGLAP, ALPL and FOSL1) and mesenchymal stem cells marker (ENG) were investigated by real time RT-PCR.

Mesenchymal stem cells are defined as selfrenewable, multipotent progenitor cells with the ability to differentiate, under adequate stimuli, into several mesenchymal lineages, including osteoblasts [17].

In present study, mesenchymal stem cells from human bone marrow were isolated and characterized by morphology and immunophenotype. Isolated

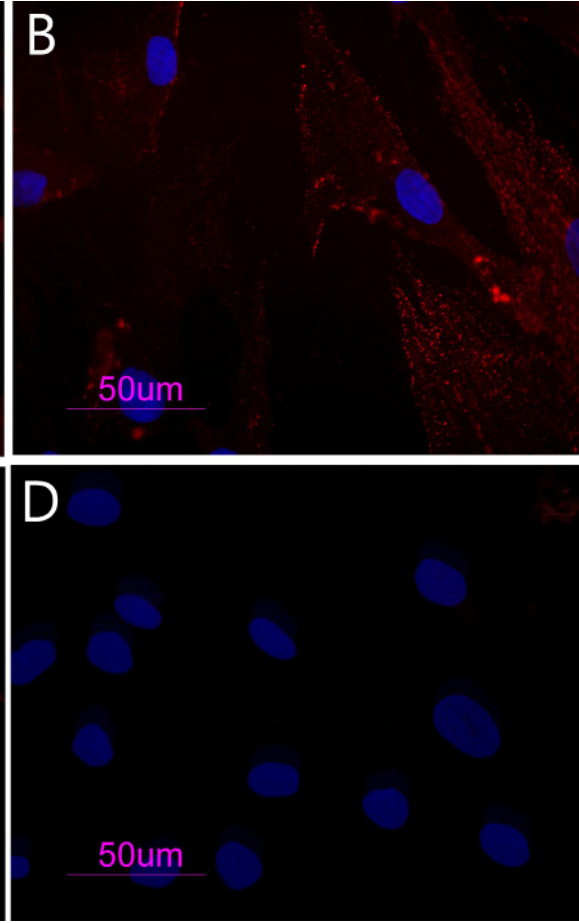

1. BM-hMSCs with indirect immunofluorescence (Rodamine). Cultured cells were egative for the hematopoietic markers CD34 (D). Nuclei were stained with DAPI. Original magnification $\mathrm{x} 40$.

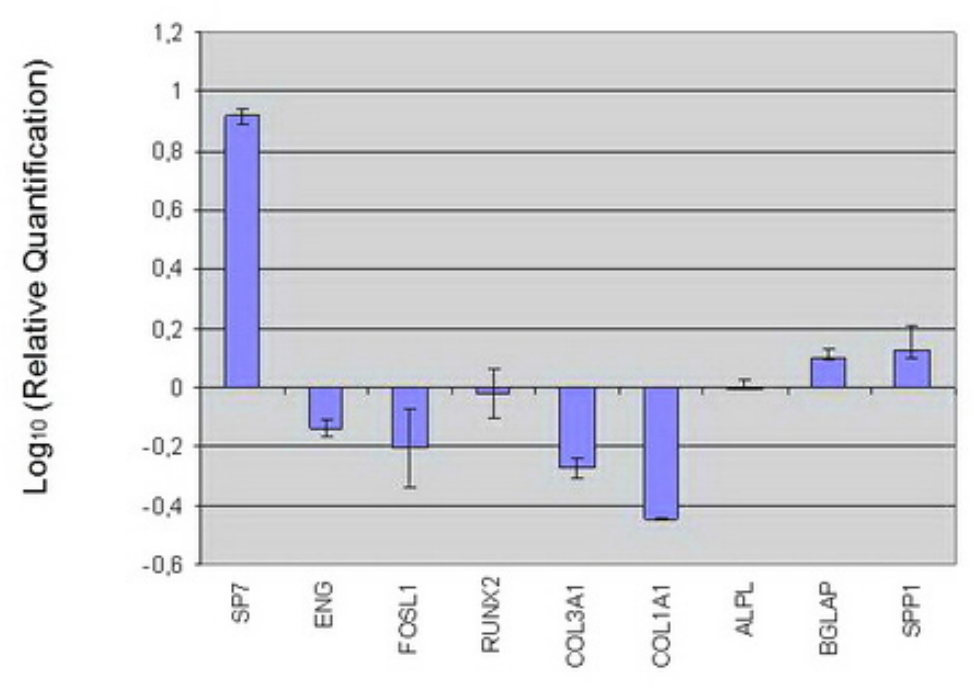

Detectors

Figure 2. Gene expression analysis of BM-hMSCs after 7 days of treatment with P-15.

BM-hMSCs showed fibroblast-like morphology and were positive for MSC surface molecules (CD90, CD105, CD73) and negative for markers of haematopoietic progenitors (CD34).

Two osteoblast-specific genes, SPP1 and BGLAP, that are generally expressed by osteoblast in the early stage of their differentiation [18], were up-regulate in treated BM-hMSCs.

Another up-regulated gene was SP7, a zinc 
finger transcription factor that regulates bone formation and osteoblast differentiation in vitro and in vivo and that is expressed in the early stage of osteogenic differentiation.

ENG (CD105), a surface markers used to define a bone marrow stromal cell population capable of multilineage differentiation [19], was down-regulated in treated BM-hMSCs respect to control. There is an inverse correlation between CD105 expression and the differentiation status of MSC [20]. This gene is a receptor for TGF- $\beta 1$ and $-\beta 3$ [21] and modulates TGF- $\beta$ signalling by interacting with related molecules, such as TGF- $\beta 1,-\beta 3$, BMP- $2,-7$, and activin A. It is speculated that these members of the TFG- $\beta$ superfamily are mediators of cell proliferation and differentiation and play regulatory roles in cartilage and bone formation [22]. The disappearance of the CD105 antigen during osteogenesis suggests that this protein, like others in the TFG- $\beta$ superfamily, is involved in the regulation of osteogenesis [23]

Expression of RUNX2 and ALPL didn't have significant change in treated cells respect to control after 7 day of treatment with P-15. RUNX2 is the most specific osteoblast transcription factor and is a prerequisite for osteoblast differentiation and consequently mineralization. This result is comparable with data reported by Kim et al. [24]. They showed that there was no BMP-2-mediated up-regulation of RUNX2 mRNA expression at days 3 or 7 , but BMP2 treatment induced a significant and time dependent increase in SP7 mRNA expression [24].

Alkaline phosphatase regulates mineralization of bone matrix. Several studies demonstrated that the potency of individual substances to induce alkaline phosphatase varies in a species-dependent manner. Glucocorticoids such as dexamethasone are potent inducers in human and rat stromal cells, but they have no effect on alkaline phosphatase activity in mouse stromal cells $[25,26]$. Instead bone morphogenetic proteins (BMPs) are potent inducers of osteogenesis in both mouse and rat bone marrow stromal cells [27]. However, Diefenderfer et al. [28] showed that BMP2 alone is a poor osteoblast inducer in human marrow derived stromal cells.

P-15 also modulates the expression of FOSL1 that encodes for Fra-1, a component of the dimeric transcription factor activator protein-1 (Ap-1), which is composed mainly of Fos (c-Fos, FosB, Fra-1 and Fra-2) and Jun proteins (c-Jun, JunB and JunD).

AP-1 sites are present in the promoters of many developmentally regulated osteoblast genes, including alkaline phosphatase, collagen I, osteocalcin (OC).

McCabe et al. [29] demonstrated that differential expression of Fos and Jun family members could play a role in the developmental regulation of bone-specific gene expression and, as a result, may be functionally significant for osteoblast differentiation.

In our study FOSL1 was down-regulated, probably because cells were at early stage of differentiation. Kim et al. [30] studying the effect of a new anabolic agents that stimulate bone formation, found that this gene was activated in the late stage of differentiation, during the calcium deposition.

P15 also modulates the expression of genes encoding for collagenic extracellular matrix proteins like collagen type $1 \alpha 1$ (COL1A1) and collagen type $3 \alpha 1$ (COL3A1). COL1A1, and COL3A1 were considerably down expressed as compared to the control when exposed to $\mathrm{P} 15$, probably because this gene are activated in the late stage of differentiation and are related to extracellular matrix synthesis.

The present study shows the effect of P-15 on BM-hMSCs in the early differentiation stages: P-15 is an inducer of osteogenesis on human stem cells but RUNX2 is not immediately activated. Moreover, we have chosen to perform the experiment after 7 days in order to get information on the early stages of stimulation.

More investigations with several different time points are needed in order to understand the molecular events related to P-15 action. This model is useful to investigate the effects of a variety of substances on stem cells.

\section{CONCLUSIONS}

The results obtained showed that P-15 participates in the initial process of differentiation of BM-hMSCs into osteoblasts, inducing expression of factors related to the differentiation like SP7, SPP1 and BGLAP.

\section{ACKNOWLEDGMENTS AND DISCLOSURE STATEMENTS}

The authors report no conflicts of interest related to this study.

This work was supported by FAR from the University of Ferrara (FC), Ferrara, Italy, and from Regione Emilia Romagna, Programma di Ricerca Regione Università, 2007-2009, Area 1B: Patologia osteoarticolare: ricerca pre-clinica e applicazioni cliniche della medicina rigenerativa, Unità Operativa n. 14. 


\section{REFERENCES}

1. Yukna RA, Callan DP, Krauser JT, Evans GH, Aichelmann-Reidy ME, Moore K, Cruz R, Scott JB. Multi-center clinical evaluation of combination anorganic bovine-derived hydroxyapatite matrix (ABM)/cell binding peptide (P-15) as a bone replacement graft material in human periodontal osseous defects. 6-month results. J Periodontol. 1998 Jun;69(6):655-63. [Medline: 9660334]

2. Bhatnagar RS, Qian JJ, Gough CA. The role in cell binding of a beta-bend within the triple helical region in collagen alpha 1 (I) chain: structural and biological evidence for conformational tautomerism on fiber surface. J Biomol Struct Dyn. 1997 Apr;14(5):547-60. [Medline: 9130077]

3. Qian JJ, Bhatnagar RS. Enhanced cell attachment to anorganic bone mineral in the presence of a synthetic peptide related to collagen. J Biomed Mater Res. 1996 Aug;31(4):545-54 [Medline: 8836852]

4. Bhatnagar RS, Qian JJ, Wedrychowska A, Sadeghi M, Wu YM, Smith N. Design of biomimetic habitats for tissue engineering with P-15, a synthetic peptide analogue of collagen. Tissue Eng. 1999 Feb;5(1):53-65. [Medline: 10207189]

5. Yang XB, Bhatnagar RS, Li S, Oreffo RO. Biomimetic collagen scaffolds for human bone cell growth and differentiation. Tissue Eng. 2004 Jul-Aug;10(7-8):1148-59. [Medline: 15363171]

6. Lallier TE, Yukna R, St Marie S, Moses R. The putative collagen binding peptide hastens periodontal ligament cell attachment to bone replacement graft materials. J Periodontol. 2001 Aug;72(8):990-7. [Medline: 11526918] [doi: 10.1902/jop.2001.72.8.990]

7. Krauser JT, Rohrer MD, Wallace SS. Human histologic and histomorphometric analysis comparing OsteoGraf/N with PepGen P-15 in the maxillary sinus elevation procedure: a case report. Implant Dent. 2000;9(4):298-302. [Medline: 11307551]

8. Yukna R, Salinas TJ, Carr RF. Periodontal regeneration following use of ABM/P-1 5: a case report. Int J Periodontics Restorative Dent. 2002 Apr;22(2):146-55. [Medline: 12019710]

9. Yukna RA, Krauser JT, Callan DP, Evans GH, Cruz R, Martin M. Thirty-six month follow-up of 25 patients treated with combination anorganic bovine-derived hydroxyapatite matrix (ABM)/cell-binding peptide (P-15) bone replacement grafts in human infrabony defects. I. Clinical findings. J Periodontol. 2002 Jan;73(1):123-8. [Medline: 11846193] [doi: 10.1902/jop.2002.73.1.123]

10. Schilephake H. Bone growth factors in maxillofacial skeletal reconstruction. Int J Oral Maxillofac Surg. 2002 Oct;31(5):469-84. Review. [Medline: 12418561]

11. Barboza EP, de Souza RO, Caúla AL, Neto LG, Caúla Fde O, Duarte ME. Bone regeneration of localized chronic alveolar defects utilizing cell binding peptide associated with anorganic bovine-derived bone mineral: a clinical and histological study. J Periodontol. 2002 Oct;73(10):1153-9. [Medline: 12416773] [doi: 10.1902/jop.2002.73.10.1153]

12. Carinci F, Pezzetti F, Volinia S, Laino G, Arcelli D, Caramelli E, Degidi M, Piattelli A. P-15 cell-binding domain derived from collagen: analysis of MG63 osteoblastic-cell response by means of a microarray technology. J Periodontol. 2004 Jan;75(1):66-83. [Medline: 15025218] [doi: 10.1902/jop.2004.75.1.66]

13. Palmieri A, Pezzetti F, Brunelli G, Martinelli M, Lo Muzio L, Scarano A, Degidi M, Piattelli A, Carinci F. Peptide-15 changes miRNA expression in osteoblast-like cells. Implant Dent. 2008 Mar;17(1):100-8. [Medline: 18332763] [doi: 10.1097/ID.0b013e318166d182]

14. Palmieri A, Pezzetti F, Brunelli G, Zollino I, Scapoli L, Martinelli M, Arlotti M, Carinci F. Differences in osteoblast miRNA induced by cell binding domain of collagen and silicate-based synthetic bone. J Biomed Sci. 2007 Nov; 14(6):77782. Epub 2007 Jul 25. [Medline: 17653614]

15. Smiler D, Soltan M, Lee JW. A histomorphogenic analysis of bone grafts augmented with adult stem cells. Implant Dent. 2007 Mar;16(1):42-53. [Medline: 17356371] [doi: 10.1097/ID.0b013e3180335934]

16. Livak KJ, Schmittgen TD. Analysis of relative gene expression data using real-time quantitative PCR and the 2(-Delta Delta C(T)) Method. Methods. 2001 Dec;25(4):402-8. [Medline: 11846609] [doi: 10.1006/meth.2001.1262]

17. Alhadlaq A, Mao JJ. Mesenchymal stem cells: isolation and therapeutics. Stem Cells Dev. 2004 Aug;13(4):436-48. Review. [Medline: 15345137 ] [doi: 10.1089/scd.2004.13.436]

18. Lian JB, Stein GS, Aubin JE. Bone formation: maturation and functional activities of osteoblast lineage cells. In: MJ Favus, editor. Primer on the metabolic bone diseases and disorders on mineral metabolism Washington D.C: The American Society for Bone and Mineral Research; 2003. p. 13-28.

19. Pittenger MF, Mackay AM, Beck SC, Jaiswal RK, Douglas R, Mosca JD, Moorman MA, Simonetti DW, Craig S, Marshak DR. Multilineage potential of adult human mesenchymal stem cells. Science. 1999 Apr 2;284(5411):143-7.

[Medline: 10102814] [doi: 10.1126/science.284.5411.143]

20. Jin HJ, Park SK, Oh W, Yang YS, Kim SW, Choi SJ. Down-regulation of CD105 is associated with multi-lineage differentiation in human umbilical cord blood-derived mesenchymal stem cells. Biochem Biophys Res Commun. 2009 Apr 17;381(4):676-81. Epub 2009 Feb 27. [Medline: 19250924] [doi: 10.1016/j.bbrc.2009.02.118]

21. Barry FP, Boynton RE, Haynesworth S, Murphy JM, Zaia J. The monoclonal antibody SH-2, raised against human mesenchymal stem cells, recognizes an epitope on endoglin (CD105). Biochem Biophys Res Commun. 1999 Nov;265(1):134-9. [Medline: 10548503] [doi: 10.1006/bbrc.1999.1620] 
22. Jakob M, Démarteau O, Schäfer D, Hintermann B, Dick W, Heberer M, Martin I. Specific growth factors during the expansion and redifferentiation of adult human articular chondrocytes enhance chondrogenesis and cartilaginous tissue formation in vitro. J Cell Biochem. 2001 Mar 26;81(2):368-77. [Medline: 11241676] [doi: 10.1002/1097-4644]

23. Haynesworth SE, Baber MA, Caplan AI. Cell surface antigens on human marrow-derived mesenchymal cells are detected by monoclonal antibodies. Bone. 1992;13(1):69-80. [Medline: 1316137]

24. Kim IS, Song YM, Cho TH, Park YD, Lee KB, Noh I, Weber F, Hwang SJ. In vitro response of primary human bone marrow stromal cells to recombinant human bone morphogenic protein-2 in the early and late stages of osteoblast differentiation. Dev Growth Differ. 2008 Sep;50(7):553-64. [Medline: 19238726] [doi: 10.1111/j.1440-169X.2008.01052.x] [Free Full Text]

25. Leboy PS, Beresford JN, Devlin C, Owen ME. Dexamethasone induction of osteoblast mRNAs in rat marrow stromal cell cultures. J Cell Physiol. 1991 Mar;146(3):370-8. [Medline: 2022691]

26. Beresford JN, Joyner CJ, Devlin C, Triffitt JT. The effects of dexamethasone and 1,25-dihydroxyvitamin D3 on osteogenic differentiation of human marrow stromal cells in vitro. Arch Oral Biol. 1994 Nov;39(11):941-7. [Medline: 7695507] [doi: 10.1016/0003-9969(94)90077-9]

27. Balk ML, Bray J, Day C, Epperly M, Greenberger J, Evans CH, Niyibizi C. Effect of rhBMP-2 on the osteogenic potential of bone marrow stromal cells from an osteogenesis imperfecta mouse (oim). Bone. 1997 Jul;21(1):7-15. [Medline: 9213002] [doi: 10.1016/s8756-3282(97)00075-6]

28. Diefenderfer DL, Osyczka AM, Garino JP, Leboy PS. Regulation of BMP-induced transcription in cultured human bone marrow stromal cells. J Bone Joint Surg Am. 2003;85-A Suppl 3:19-28. [Medline: 12925605] [Free Full Text]

29. McCabe LR, Banerjee C, Kundu R, Harrison RJ, Dobner PR, Stein JL, Lian JB, Stein GS. Developmental expression and activities of specific fos and jun proteins are functionally related to osteoblast maturation: role of Fra-2 and Jun D during differentiation. Endocrinology. 1996 Oct;137(10):4398-408. [Medline: $\underline{828501]}$

30. Kim JM, Lee SU, Kim YS, Min YK, Kim SH. Baicalein stimulates osteoblast differentiation via coordinating activation of MAP kinases and transcription factors. J Cell Biochem. 2008 Aug 1;104(5):1906-17. [Medline: 18384125] [doi: 10.1016/s8756-3282(97)00075-6]

\section{To cite this article:}

Sollazzo V, Palmieri A, Girardi A, Farinella F, and Carinci F. Early effects of P-15 on human bone marrow stem cells.

J Oral Maxillofac Res 2010 (Jan-Mar);1(1):e4

URL: http://www.ejomr.org/JOMR/archives/2010/1/e4/e4ht.pdf

doi:10.5037/jomr.2010.1104

Copyright $($ C Sollazzo V, Palmieri A, Girardi A, Farinella F, and Carinci F. Accepted for publication in the JOURNAL OF ORAL \& MAXILLOFACIAL RESEARCH (http://www.ejomr.org/), 26 November 2009.

This is an open-access article, first published in the JOURNAL OF ORAL \& MAXILLOFACIAL RESEARCH, distributed under the terms of the Creative Commons Attribution-Noncommercial-No Derivative Works 3.0 Unported License, which permits unrestricted non-commercial use, distribution, and reproduction in any medium, provided the original work and is properly cited. The copyright, license information and link to the original publication on (http://www.ejomr.org) must be included. 